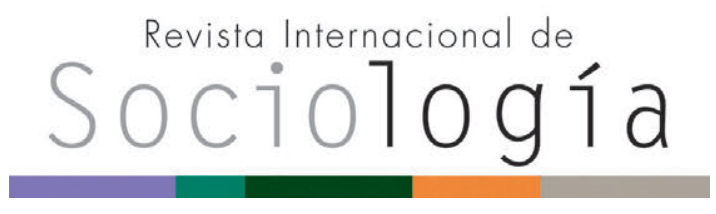

Revista Internacional de Sociología RIS vol. 74 (4), e049, octubre-diciembre, 2016, ISSN-L:0034-9712 doi: http://dx.doi.org/10.3989/ris.2016.74.4.049

\section{MOVEMENT AND EMPOWERMENT: Explaining the Political Consequences of Activism}

\author{
Sofia HELANDER \\ Uppsala University \\ sofia.helander@statsvet.uu.se
}

Cómo citar este artículo / Citation: Helander, S. 2016. "Movement and Empowerment: Explaining the Political Consequences of Activism". Revista Internacional de Sociología 74 (4): e049. doi: http://dx.doi.org/10.3989/ ris.2016.74.4.049

\section{Abstract}

In follow-up studies of activists, activism has been observed to have long-term positive effect on political participation. However, little attention has been paid to the conditions under which the theory applies. I examine how the personal consequences of participation in three different protest movements in Sweden depended upon movement success and procedural justice. The results support previous findings suggesting that activism has positive long-term effects on individual political participation. However, several of the activists interviewed did not follow this general pattern, especially those who suffered unfair and discriminatory treatment from the authorities. The results imply that the effect of activism on political participation is determined by the perceived procedural justice, whereas reaching the preferred policy outcome is of less importance. External political efficacy is indicated to be a potential mechanism explaining the relation between activism and long-term political participation.
\end{abstract}

\section{KEYWORDS}

Biographical Outcomes; Political Efficacy; Political Participation; Procedural Justice; Social Movements.
Copyright: (C) 2016 CSIC. This is an open-access article distributed under the terms of the Creative Commons Attribution License (CC BY) Spain 3.0.

Received: 20/12/2015. Accepted: 01/07/2016. Published on line: 21/10/2016

\section{REsumen}

En estudios de seguimiento a activistas se ha observado que el activismo tiene efectos positivos a largo plazo sobre la participación política. Sin embargo, se ha prestado poca atención a las condiciones en las que se aplica esta teoría. Este artículo examina cómo las consecuencias personales de la participación dependieron del éxito del movimiento y la justicia procesal en tres movimientos diferentes de protesta en Suecia. Los resultados apoyan hallazgos previos que sugieren que el activismo afecta de manera positiva a largo plazo sobre la participación política individual. Sin embargo, varios de los activistas entrevistados no siguieron este patrón general, especialmente entre quienes sufrieron un trato injusto y discriminatorio por parte de las autoridades. Los resultados sugieren que el efecto del activismo en la participación política viene determinado por la justicia procesal percibida. Al mismo tiempo, ganar la política que perseguía la protesta resulta de menor importancia. También se muestra que la eficacia política externa es un mecanismo potencial que explica la relación entre el activismo y la participación política a largo plazo.

\section{Palabras Clave}

Consecuencias Biográficas; Eficacia Política; Justicia Procedimental; Movimientos Sociales; Participación Política. 
Equal political participation is fundamental to democracy (e.g. Dahl 2000:38). However, in reality, equal participation is not fully achieved in any democracy; the voices that are least heard are often those of the most exposed and disadvantaged (Verba, Nie and Kim 1978; Schlozman, Verba and Brady 2012). There are some forms of participation, based on collective action, where the inequality of participation is less pronounced (Verba, Brady and Schlozman 1995:191).

Social movements have a particular potential to mobilize people across socio- economical boundaries (Verba, Brady and Schlozman 1995:191). Furthermore, research into the biographical and political outcomes of activism indicates that activism has the potential of significantly changing an individual's life-course-empowering individuals and inspiring political engagement expanded far beyond the initial motives and time frame of the activism (see Giugni 2008:1590 for review). Thus, social movements could serve as a source of energy, triggering effective political participation and bringing new life into democracy.

However, in acknowledging the potential of social movements in mobilizing marginalized groups and triggering long-term political participation, we must also consider how this potential could be fulfilled. The literature on the biographical outcomes of social movements has paid little attention to the mechanisms through which activism inspires further political engagement and to the many obstacles that might block these mechanisms.

Through the movement, some activists have their first contact with the political authorities. And while some are positively surprised, many are gravely disappointed. Thus, the relationship between activism and further political engagement is likely to be affected by factors such as the success of the movement and whether the activist found themselves fairly responded to by public officials. While social movement studies have investigated the effects of the political context on policy outcomes and movement formation (Tarrow 1998:71-90), the effects of the political context on individual level outcomes have received little attention. Consequently, the conducted studies of the biographical consequences of activism have been built on the underlying assumption that the effects of movement participation are the same, irrespective of policy outcome and experiences of procedural justice. Such assumptions could be questioned given the results of studies in related fields. For example, individuals participating in various political activities who have experienced unfair treatment by the authorities have reported diminished efficacy beliefs. Diminished political efficacy is also likely to negatively affect the levels of political participation (Westholm and Erlach 2007:285).
Thus, further work is needed in order to understand the relationship between activism and political participation found in previous research. In particular, the effect of factors such as the perceived justice of the procedure and political efficacy beliefs needs to be further examined. The aim of this study is to fill these gaps.

For this purpose, I will study and compare protests against school closure in Sweden. In Sweden, closure of local welfare facilities, such as schools or hospitals, stir up strong emotions and evoke massive protests. These types of protests, which have grown increasingly common since the 1990s (Uba 2010:96), have the possibility to draw people from a broad spectrum of society, mobilized by their personal commitment to the issue.

Three cases of protests against school closure in the city of Helsingborg, during 2003 are selected. During a number of intense months, people marched the streets of the city, meetings and manifestations were held, politicians were contacted and names were collected. The political climate in Helsingborg completely changed. Hundreds of people, many of whom had never before participated in any political activity apart from voting, were mobilized and several new organizations were created.

Ten years after the protests, 80 interviews with parents and teachers protesting against the closure of three different schools in Helsingborg, and control groups of parents not taking part in the movement, were conducted. I trace the individual political consequences of activism and examine how these take shape depending on the level of individual activism, the success of the movement in reaching its policy goals, the perceived fairness of the political decisionmaking process, and the development of political efficacy beliefs of the participants and other potential mechanisms.

\section{Political Participation as an Individual Consequence of Activism}

\section{Political and Biographical Outcomes of Activism}

In 1999, Doug McAdam noted that only a few follow-up studies had been made of former movement activists (117). Moreover, the research on the biographical consequences is in general homogenous in terms of both focus and case selection.

The majority of the work focuses on the European and North American New Left cycle of contentions of the 1960s (Giugni 2004: 491). In latter studies a larger number of subjects are included. This body of work includes Sherkat and Blocker's follow-up study of participants in anti-war and student protests of the late 1960s, as well as studies by McAdam (1999), Wilhelm (1998), and Van Dyke, McAdam and Wilhelm (2000). These large-scale studies are mainly 
focused on macro-level demographic changes, seeking to examine how the movements of the New Left could help to explain demographic trends (see Giugni 2004 and 2008 for review).

The follow-up studies of activists provide a consistent picture of the personal social movement consequences. The results indicate that former movement participants have lower income, are more likely to be divorced, more likely to have experienced episodic work history, are more educated and less likely to have children (Giugni 2008:1590). Concerning the political consequences, former activists maintained leftist attitudes and continued to define themselves as liberal or radical (ibid. 1590).

The effect on individual level participation is briefly examined in a few of the studies. In general, the results indicate that activists remain politically active, often in contemporary movements (Giugni 2008:1589; Sherkat and Blocker 1997:1061). However, contradictory results have also been indicated. In McAdam and Brandt's (2009) follow-up study of accepted applicants to Teach for America 1993-98, a lower degree of civic engagement was observed among the graduates of the program than among the control group of non-matriculates and drop-outs (Brandt and McAdam 2009:952). However, McAdam and Brandt emphasize that the results are probably not due to the fact that participation in the program had reduced future participation. Instead, they point at methodological shortcomings as potential explanations.

\section{Methodological Challenges in the Follow-up Studies of Activists}

Scholars have identified a number of problems with earlier studies of the biographical outcomes of activism, which still remain, to a large extent, in later studies (Giugni 2008; McAdam 1999). Most studies focus on similar movements from the same place and period of time and include only a small number of subjects. Thus, the possibilities of drawing generalized conclusions based on them are limited (McAdam 1999). Only a few of the studies have more than 40 respondents. In addition, the design of many of the studies makes it difficult to determine the causality of a perceived effect of social movement involvement. Half of them lack control groups of non-participants, and consequently there is no base line against which to compare the activity. Moreover, gathering before and after data on the subjects poses a methodological challenge. In most follow up-studies of activists, no information about the activists is collected prior to their participation in the movement (McAdam 2009:947; 1999:121).

In addition to the methodological shortcomings discussed in previous work, there is one potential issue which has only been briefly touched upon: the prob- lem of selection bias. McAdam and Brandt (2009) suggest that the selection bias could possibly explain the surprising results of their study of the Teach for America-program, where a lower degree of civic engagement was observed among the graduates of the program than among the control group of non-matriculates and drop-outs. The selection bias results in a sampling which is not representative for the population at large. The subjects all actively sought out a politically engaged life-course by applying to the TFA-program. Participants in leftist movements and activists in educational programs are likely to come from activist families and carry deep rooted values that are difficult to control for (966).

This problem remains in the majority of the studies on the biographical consequences of activism (see Giugni 2008 for review). There is therefore a risk that the found relations in previous studies could be spurious, explained by confounders such as "taste" for activism (Verba, Brady and Schlozman 1995:336). In this study I attempt to reduce the selection bias by studying cases where people are "compelled" into activism by political events strongly affecting their own personal lives.

\section{Explaining the Political Consequences of Activism}

The studies of the political consequences of activism have focused on whether there are biographical consequences of social movement participation. Few attempts have been made to examine under which conditions such effects take place or how they can be explained. Hypotheses of this could be formed based on findings from studies on political participation, political efficacy and participatory democracy.

\section{Explaining Political Participation}

Research into political participation has identified a number of factors explaining political mobilization. Several of these motivations and resources are likely to also be affected by participation in social movements.

Political participation could be explained by several factors, summarized by Brady, Verba and Schlozman (1999) in their civic voluntarism model. They identify three different components explaining political mobilization: motivations, resources and recruitment (431). In order to participate, an individual must have the resources necessary to make a particular activity possible. These involve wealth, education, time and prestige (Verba, Nie and Kim 1978:11). In addition, the individual in question must choose to use this opportunity - have motivations to participate. These motivations could be interest in politics and political efficacy, such as belief in one's ability to affect public issues. If an individual has the necessary capacity and engagement, they will be more likely to participate if asked to if they have access to networks of recruitment (Verba, Brady and Schlozman 1999:431; 1995:3). 
Participation in each mode could be explained differently. Voting is affected by sense of citizen duty and party identification. Contacting is influenced by political interest, internal political efficacy and broad social networks. Partisan activity is determined by factors such as private networks, political interest, and party identification, as well as internal and external political efficacy. Protesters often have a high sense of external political efficacy in relation to the specific activity, and are generally more left-wing (Armingeon 2007:380).

The factors fostering political activity have been found to develop early in life and to be stocked over time. They are distributed unequally, where upper-status individuals are frequently conferred additional advantage (Verba, Brady and Schlozman 1995:4). This could explain the distortions in political participation, where upper-status individuals participate politically to a higher extent. However, Verba, Brady and Schlozman also find that there are factors which could enhance resources, motivations and networks. Most notably, institutions such as schools, voluntary associations and churches are found to have a positive effect on mobilizing factors (ibid. 4). These findings indicate that changes of social context and participation in a collaborative environment could affect mobilization and equality of participation.

While some individual resources and motivations are difficult to change, others are more easily affected. Networks of recruitment, interest and knowledge in politics, and political efficacy are mobilizing mechanisms that are also likely to be affected by activism. Consequently, these factors could be hypothesized to serve as mechanisms explaining the individual political consequences of activism.

\section{Political Efficacy Depending on Policy Outcome and Procedural Justice}

Political efficacy is commonly identified as a mobilizing resource explaining political participation (Sullivan and Riedel 2001:4353). The concept has been found to consist of two separate elements, internal and external efficacy, with differing characteristics. External Efficacy is defined as "beliefs about the responsiveness of governmental authorities and institutions to citizen demands" (Niemi, Craig and Mattei 1991:1408). Internal efficacy is defined as "beliefs about one's own competence to understand and to participate effectively in politics" (Ibid. 1407).

A more limited amount of research also finds political efficacy to be affected by political participation (Finkel 1987:443). Interestingly, participation is found to not only have a positive effect on political efficacy - negative experiences of political engagement have been proven to have negative effects on concepts related to internal efficacy (Levy 2013:359).
In particular, experience could relate to outcome and process. Research into small-scale democracy (e.g. Westholm and Erlach 2007) and direct democracy (e.g. Frey and Stutzer 2006) have found the experience of the outcome and process of political activity to be of particular importance in determining the effect on political efficacy ${ }^{1}$. If the preferred outcome is reached or the procedure of political decision-making is perceived as just, the positive effect of political participation on political efficacy is strengthened (Westholm and Erlach 2007:286; Frey and Stutzer 2006:393). The notion of procedural justice refers to the feeling that one's preferences "seriously have been taken into account in a fair political process" (Frey and Stutzer 2006: 393). In contrast to previous research, Frey and Stutzer (2006) find procedural justice to generate even more utility than that gained from reaching the preferred policy outcome (ibid. 393).

Sometimes, citizen demands cannot be satisfied due to reasons such as lack of resources. However, unsatisfied demands do not necessarily result in diminishing efficacy-beliefs among the active citizens, given that the process was perceived as fair (Westholm and Erlach 2007: 285). Thus, perceived procedural fairness, where citizens perceive that they are treated with respect and are provided with reasonable explanation as to the decision, is implied to be a crucial factor in determining political efficacy beliefs (ibid. 285).

In sum, research into political efficacy indicates that there could be a spin-off effect of participation, functioning through the mechanism of political efficacy. However, the effect of movement activism on participation may vary depending on the experience of the activism. Efficacy beliefs and, consequently, the degree of political participation, are indicated to be shaped by first-hand experiences of the system and its institution. The degree to which the preferred policy outcome is reached and the political process is considered fair (procedural justice) are indicated as factors of particular importance in determining the relation between activism and long-term political engagement.

When returning to the concepts of equal participation, these results have interesting implications. Early experiences of political mobilizations are indicated to lead to the formation of positive and negative feedback loops. When the system is experienced as responsive or fair, activism could result in increased sense of political efficacy and, thus, in continued political participation. On the contrary, unfair treatment by government officials or institutions could result in decreased political efficacy beliefs and, consequently, less political participation. At the same time, there is a risk that marginalized or socio-economically disadvantaged groups are met with less responsiveness and respect by public officials. 


\section{THE STUDY}

\section{Sampling and Data Collection}

The study focuses on three movements protesting against school closure in Helsingborg during the year of 2003 and 2004. In contrast to the highly ideological movements that have been the focal point of previous follow-up studies of activists, movements against school closure have the ability to mobilize people on a broad scale, irrespective of previous interest in politics or attitudes towards activism. Parents, teachers and pupils are compelled into activism for their own, their children's or their pupil's sake. Thus, the risk of bias due to self-selection is reduced.

The specific cases of protest against school closure were selected due to their high comparability with regards to place and timing and to their differing policy outcomes, with one movement reaching their policy goal of stopping the school closure and two movements which did not.

The personal and biographical consequences of activism are studied on a micro-level through followup studies of activists. 80 interviews were conducted with teachers and parents of pupils at the three selected schools ten years after their participation in the movement. Within the group of parents and teachers at the three schools, a stratified sampling with respect to sex and school was made. Thirty-four of the respondents had been teachers or parents of pupils at Gustav Adfolfsskolan, 24 at Slottsvångsskolan and 30 at Norrhedskolan. Half of the respondents from each school were women. In order to ensure that the most active participants were included in the selection, protesters referred to by the first informants or mentioned in newspapers, were selected. The remaining quota from each school was drawn randomly from the list of students at each school for the relevant school year. The randomly selected respondents who did not participate in the movement were taken as a control group of non-participants. Approximately half of the respondents were active in the struggle against school closure.

Seven of the selected respondents were not interviewed, resulting in a response rate of approximately 91 per cent. Two of the respondents did not want to participate, while five could not be reached. For the sake of upholding precision, seven new respondents were selected from the relevant strata.

In order to achieve a high response rate, the data was collected by telephone interviews. The interview format has the advantage of allowing open, less guided questions to be asked, and preventing misunderstandings. Moreover, the discussions held during the conversations could help the respondents to gradually remember more of the story. However, the choice of interview format also increases the risk of a desirability bias affecting the respondents. This is taken into consideration in the formulation of the questions, where efforts are made to underline that non-participation is understandable and common. Moreover, the respondent's names are only used in the study when explicit consent was given. However, desirability bias is difficult to completely avoid. This is taken into consideration when analysing the results.

The interviews are semi-structured, taking particular care to cover the full concept of political participation at each period of time. The interview length varied from approximately 10 to 30 minutes. Some of the interviews, where no political participation is observed, are very short, while others, especially those with activists reporting high levels of activity in the movement, are much longer. The interviews were centred on the respondents' political participation, political efficacy and experience of the protests. The interview guide can be found in the appendix.

\section{Hypothesises and Measures}

The study examines two types of hypothesis. First, I examine the conditions under which the effect of activism on long-term political participation is triggered. The 'conditions' of the effects refers to the situation or experience of the activism itself. I examine what type of experiences of activism could trigger the effect on long-term participation. A number of hypothesis derived from previous research are tested. Variables related to the experience of the movement, which in previous research have been indicated to affect political participation, directly or indirectly through potential mechanism, include perceived procedural justice and reaching preferred policy. I assume that a positive effect of activism on long-term political participation is more likely to be triggered if the receptions of the movement by the public authorities are experienced as 'fair' and/or if the movement is successful in reaching its policy goals. Previous research also indicates that experiences of low procedural justice may also have negative effects on further political participation.

Second, I examine the mechanism explaining the effect of activism on long-term political participation. The 'mechanism' refers to the effects following from the experience of the activism. A number of hypotheses derived from previous research into political participation and mobilizing mechanisms are tested. The variables are selected based on their potential for both being affected by movement participation and affecting participation. Four variables are selected: Internal political efficacy, external political efficacy, political interest and mobilizing networks.

Before moving on to the analysis, I discuss the operationalization of key variables. Information on the operationalization of the more easily measured variables, such as the demographic factors and the potential mechanisms of political interests and mobilizing networks, can be found in the appendix. 


\section{Political Participation}

Research in the area of political participation has led to insights in what constitutes political participation, as well as how it can be measured. Political participation is here defined as "... all voluntary activities by individual citizens intended to influence either directly or indirectly political choices at various levels of the political system." (Brady et al. 1999:737). Political participation includes activity within five modes: voting, campaign work, communal activity, contacting public officials, protesting and political organization (Verba, Brady and Schlozman 1995:544). Due to the difficulties of weighting the modes of participation (see discussion in Brady et al 1999:737-796), I measure political participation as a simple dummy variable, where political participation in any mode except for voting yields a point. However, considering the specific nature of the mode of voting as a particularly common form of participation, but which is only weakly related to participation in other modes, voting is not included in the measurement. Thus, the term "political participation" here refers to political participation within modes other than voting.

As the study examines change in political behaviour, political participation would ideally have been measured at several points in time. As in most follow-up studies of activists, this is not possible. Instead, I rely on the respondents' own description of their past behaviour.

The respondents are asked about their participation at three points of time: before the movement $\left(t_{0}\right)$, during the movement $\left(t_{1}\right)$, and after the movement $\left(t_{2}\right)$. In addition, in order to be able to study the long-term effects, the participation during the last 12 months of $t_{2}$ is measured separately. No participation directly connected to the movement, such as in organisations created as a part of the movement, remains today. Consequently, the participation during the period of the last 12 months includes only activities separate from those of the movement.

In the variable of participation during the movement, only political participation in the movement is included. Only very few of the respondents participated in other forms of political activities during the period of the movement, where all of the latter had also been politically active during the period before the movement. Consequently, other participation during the time of the movement has no relevant effect on the results and is, therefore, not included in the analysis.

The period of the movement is specified as the time period from the proposed closure to the closure/ decision of non-closure. The period differs somewhat for the three studied movements. Figure 1 illustrates the approximate time period of movement activity of each movement.
The struggle against school closure during the time period of $t_{1}$ is mainly measured as a simple dummy variable: 'participated' or 'did not participate'. Moreover, in order to enable studies of the threshold-value of activism necessary for the triggering of political consequences, an additional measurement of 'high level of participation' is added.

In order to minimize reliability problems due, for example, to the problems inherent in retrospective studies, a simple dummy variable "high level of participation" is used. Frequent participation yields the value of one and any less participation yields the value of zero. Most of the politically active respondents either participated in one event, such as a demonstration, or participated very actively and frequently. Thus, although the reliability problems are far from eliminated, making a distinction between high and low level of participation proved to be easier than expected.

\section{Perceived Political Efficacy}

As with political participation, the notion of political efficacy has developed over time. In the first studies on the subject, the notion of "sense of political efficacy" was defined as "the feeling that individual political action does have, or can have, an impact upon the political process" (Campbell, Gerald and Miller 1954:187). More recent studies have found political efficacy to consist of two separate components, internal and external political efficacy, which are mutually exclusive, as well as differently related to other variables (Niemi and Westholm 1986:61).

External Efficacy is defined as "beliefs about the responsiveness of governmental authorities and institutions to citizen demands" (Niemi, Craig and Mattei 1991:1408). Some examples of indicators of external efficacy are the responses to the following statements, in terms of agreement or disagreement. ${ }^{2}$ The answers noted in parentheses indicate a high degree of external efficacy.

- There are many legal ways for citizens to successfully influence what the government does. (agree)

- In this country, a few people have all the political power and the rest of us are not given any say about how the government runs things. (disagree)

- If public officials are not interested in hearing what the people think there is really no way to make them listen. (disagree).

- Most public officials are truly interested in what the people think. (agree)

(Craig, Niemi and Silver 1990:307)

Internal efficacy is defined as "beliefs about one's own competence to understand and to participate effectively in politics" (Niemi, Craig and Mattei 


\section{Figure 1.}

The Period of Movement Activity in each Movement

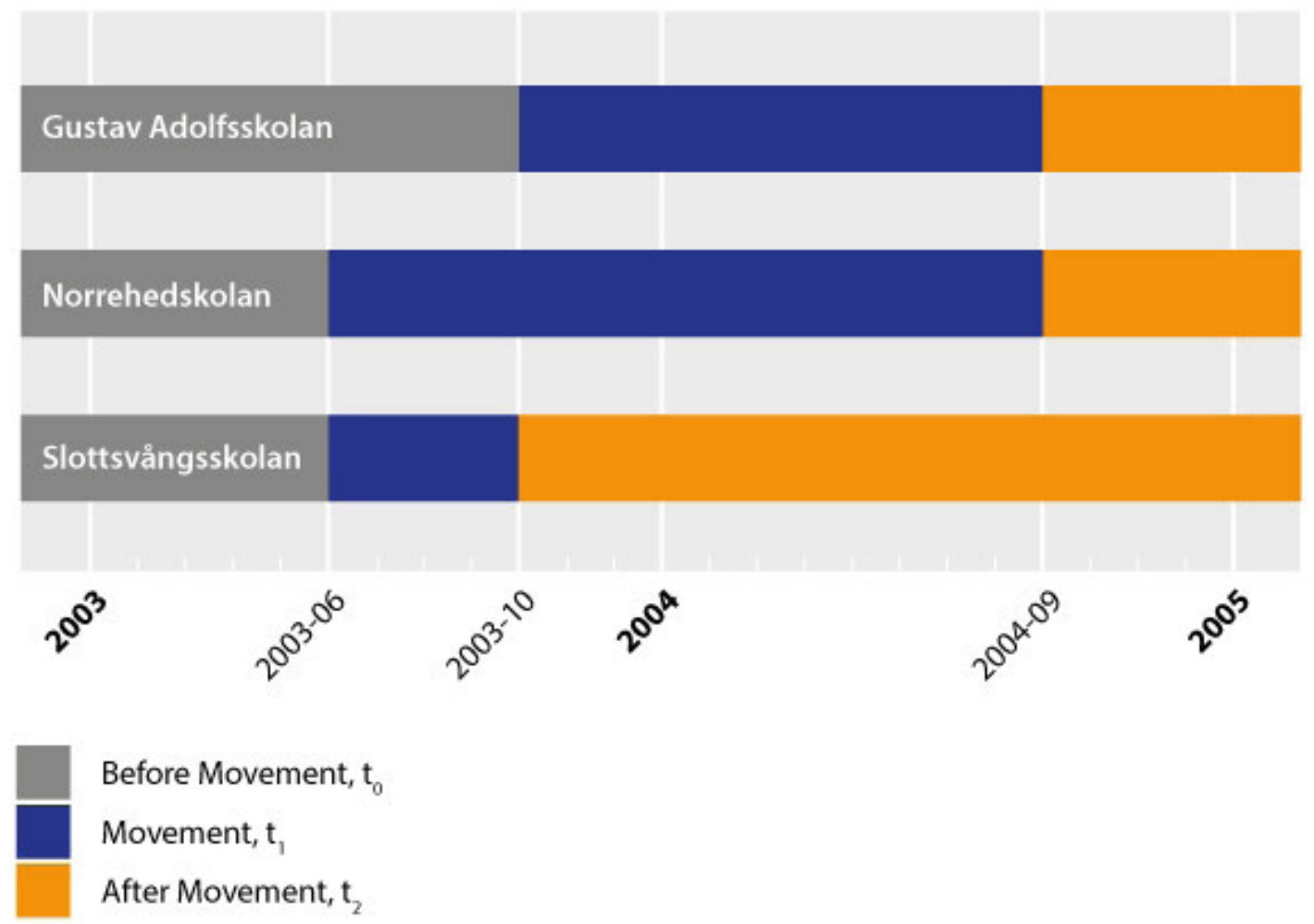

1991:1407). Indicators of internal efficacy are identified in accordance with those formulated by Niemi, Craig and Mattei (1990:1408):

- I consider myself to be well qualified to participate in politics.

- I feel that I have a pretty good understanding of the important political issues facing our country.

- I feel that I could do as good a job in a public office as most other people.

- I think that I am better informed about politics and government than most people.

In measuring political efficacy among interviewed subjects, questions related to political efficacy are posed. The interviews are carried out in a freer format and open questions are posed, such as: "Do you, in general, believe that activities other than voting could affect political decisions"? When no indication statements are given in answer to the open questions, more specific questions are asked.

The use of interview material rather than survey data means a higher risk of reliability problems. A simple distinction of high and low efficacy is employed, thereby aiming at increasing the reliability of the measurements. In order to minimize these problems, close notes were taken during the interviews, for most parts capturing the exact wording of the respondents. The interviews were then closely analysed. The example statements above are used as guidelines when categorizing the results.

Table I illustrates how efficacy could be operationalized.

Due to the intrinsic problem in measuring attitude variables in retrospective studies, political efficacy, as well as the other mechanism variables, is solely measured at the present period of time, $t_{2}$.

\section{Perceived Procedural Justice and Policy Outcome}

The focus is on the subjective experiences of the movement participants. As a result, there is no need to determine whether policy success or failure depended upon the protests or if the process objectively could be considered fair. The variable of reaching preferred policy outcome is operationalized as movement success or failure, where school closure is categorized as failure, and no closure as success. Consequently, the movement at Slottsvångsskolan is considered as a successful movement, while the movement at Gustav Adolfsskolan and Norrehedskolan are categorized as unsuccessful.

Perceived procedural justice is operationalized as the protesters' subjective experiences of the process 
Table I.

Examples of High and Low Political Efficacy ${ }^{a}$

\begin{tabular}{|c|c|c|}
\hline & \multicolumn{2}{|c|}{ Political Efficacy } \\
\hline & HIGH & LOW \\
\hline $\begin{array}{l}\text { Internal } \\
\text { "Beliefs about one's own competence } \\
\text { to understand and to participate ef- } \\
\text { fectively in politics" }\end{array}$ & $\begin{array}{l}\text { "I'm not really that involved with politics } \\
\text { and stuff, but I know what's right and } \\
\text { what's wrong and what to do when push } \\
\text { comes to shove." } \\
\text { (Man, Norrehedsskolan) }\end{array}$ & $\begin{array}{l}\text { "I read the newspapers. But } \\
\text { I can't say I really know what } \\
\text { would be the best decision in } \\
\text { most situations. So it's only rea- } \\
\text { sonable that the politicians don't } \\
\text { listen so much. They probably } \\
\text { know the best." (Man, Gustav } \\
\text { Adolfsskolan) }\end{array}$ \\
\hline $\begin{array}{l}\text { External } \\
\text { "Beliefs about the responsiveness of } \\
\text { governmental authorities and institu- } \\
\text { tions to citizen demands" }\end{array}$ & $\begin{array}{l}\text { "With the right strategies and arguments } \\
\text { it's always possible to have some influ- } \\
\text { ence. If nothing else works, it might be } \\
\text { necessary to do it through a party. You } \\
\text { can always force politicians to listen." } \\
\text { (Man, Norrehedskolan) }\end{array}$ & $\begin{array}{l}\text { "People have no say in politics. } \\
\text { When politicians have made up } \\
\text { their minds, they will not change } \\
\text { their view, no matter what you do." } \\
\text { (Woman, Gustav Adolfsskolan) }\end{array}$ \\
\hline
\end{tabular}

${ }^{a}$ All quotes from respondents are translations by the author.

and whether the response of government officials was considered fair. Consequently, the indicators concern the procedure rather than outcome and relate to the concept of fairness. The variable is measured dichotomously as fair or unfair. The indicators are given from open questions on the experience of the movement such as: "How did the politicians/public officials react to your activities?"

Respondents are indicated to have experienced high procedural justice if they describe that they were given a fair chance by public officials, that their demands were considered seriously, and that reasonable explanations were given to them by public officials. In contrast, statements pointing at a perceived lack of fairness such as "they just closed the school, we were given no explanations" or "the politicians only listened to 'Swedish' people and not to us" indicate low procedural justice.

There is a large variation in the degree to which a procedure may be considered as just among those respondents who were categorized as having generally experienced the procedure as unfair. Therefore, an additional measurement of fairness, capturing very unfair treatment, has been added. The variable is dichotomous and divided into very unfair and minimum level of fairness. The measurement covers very unfair treatments experienced at a more personal level, such as discrimination due to race or ethnicity, very degrading treatment by politicians, or feelings of humiliation in the process. Unfair treatment that would not be considered very unfair would, for example, be polite treatment by politicians, but where politicians did not take arguments into fair consideration. It should be noted that the category of very unfair treatment could be argued to go beyond the notion of procedural justice as it is commonly understood. It covers an experience of disrespect and complete disregard of the perspectives presented, which might be considered to be of a somewhat different nature than procedural justice. I believe this specific experience requires further examination in order to find a more precise way of conceptualizing it. However, for the purpose of this study I will remain within the well-established framework of procedural justice. Examples of categorizations are presented in Table II.

Table II.

Measuring Procedural Justice, Examples

\begin{tabular}{|c|c|c|}
\hline \multirow[t]{2}{*}{ FAIR } & \multicolumn{2}{|c|}{ UNFAIR } \\
\hline & $\leftarrow$ Minimum Level of Fairness — & VERY UNFAIR \\
\hline $\begin{array}{l}\text { "The politicians did their best, but in } \\
\text { the end some school had to close. } \\
\text { There were no good alternatives. But } \\
\text { I do think they knew what they were } \\
\text { doing. In the end I understood their } \\
\text { decision. I think it worked out for the } \\
\text { best." (Man, Norrehedskolan) }\end{array}$ & $\begin{array}{l}\text { "They (the local politicians and } \\
\text { civil servants) were polite but did } \\
\text { not take arguments or new infor- } \\
\text { mation into fair consideration". } \\
\text { (Man, Norrehedskolan) }\end{array}$ & $\begin{array}{l}\text { "It was horrible; I still get mad thinking } \\
\text { about it. They (the local politicians) went } \\
\text { behind our backs... We were not given } \\
\text { any chance just because all of us did } \\
\text { not speak Swedish perfectly." (Woman, } \\
\text { Gustav Adolfsskolan) }\end{array}$ \\
\hline
\end{tabular}




\section{Results}

\section{The Effect of Activism on Long-Term Political Participation}

The interview material provides comprehensive information on how the participation patterns among the selected parents and teachers have changed over time. The results are shown in Table III.

Two main conclusions could be drawn. Firstly, in line with the results of previous studies, participation in the movement is found to have a long-term effect on political participation (cf. Giugni 2008). There is a significant positive effect of movement participation on participation after the movement's cessation in general, as well as on participation during the last 12 months. The effect remains significant when controlling for potential confounders, including participation before the movement. In Model 2, the coefficient for movement participation is 1.75 , which is an odds ratio of 5.75 , indicating a 5.75 odds of political participation today if you participated in the movement. Thus, the correlation seems to hold even, though it is within a very different setting from that of the American movements of the 1960s and 70s, and where attempts have been made to reduce the bias of self-selection.
Secondly, the conditions necessary in order to trigger the effect are studied. Movement success is not found to be a condition of the effect. When adding the outcome variable, a significant effect of movement participation on participation today can still be observed. The successful outcome variable has no significant effect on participation today. Consequently, it is indicated that the effect of activism on political participation could take place irrespective of movement success.

However, there is indication of a threshold-value of the level of activism necessary in order for the effect to be triggered. In Model 4, high level of political participation is the dependent variable. The coefficient is significant at the 1 per cent level and the coefficient is 2.06 , which is an odds ratio of 7.8. The effect of movement participation on future participation is shown to increase with the time spent in activism. This point is further illustrated in Figure 2.

Among the high level movement activists, 43.5 per cent of the respondents participate today. This is clearly higher than the corresponding sample population proportions among the non-participants (8\%) and the low-level participants (5\%). Consequently, it is implied that there is a threshold-value of participation needed in order to trigger the political con-

Table III.

Logistic Regression, Political Participation after the Movement $\left(t_{2}\right)$

\begin{tabular}{|c|c|c|c|c|}
\hline \multirow[t]{2}{*}{ Variables } & \multicolumn{4}{|c|}{ Political Participation at $t_{2}$} \\
\hline & $\begin{array}{l}\text { After Movement } \\
\text { Model } 1\end{array}$ & $\begin{array}{c}\text { Today }^{\mathrm{a}} \\
\text { Model } 2\end{array}$ & $\begin{array}{c}\text { Today } \\
\text { Model } 3\end{array}$ & $\begin{array}{c}\text { Today } \\
\text { Model } 4\end{array}$ \\
\hline Participation in Movement, $t_{1}$ & $\begin{array}{l}2.87^{\star \star \star} \\
(0.13)\end{array}$ & $\begin{array}{l}1.75^{\star *} \\
(0.81)\end{array}$ & $\begin{array}{l}1.83^{\star \star} \\
(0.50)\end{array}$ & \\
\hline High Level of Participation in Movement, $t_{1}$ & & & & $\begin{array}{l}2.06^{* * *} \\
(0.495) \\
\end{array}$ \\
\hline Movement success, no closure & & & $\begin{array}{l}-0.0795 \\
(0.13) \\
\end{array}$ & \\
\hline \multicolumn{5}{|l|}{ Control Variables } \\
\hline Participation Before Movement, $t_{0}$ & $\begin{array}{l}1.97 \\
(1.4) \\
\end{array}$ & $\begin{array}{l}0.872 \\
(0.88) \\
\end{array}$ & $\begin{array}{l}0.978 \\
(0.76) \\
\end{array}$ & $\begin{array}{l}0.626 \\
(1.1) \\
\end{array}$ \\
\hline Female & $\begin{array}{l}-0.876 \\
(1.2)\end{array}$ & $\begin{array}{l}-0.611 \\
(0.79)\end{array}$ & $\begin{array}{l}-0.299 \\
(0.59)\end{array}$ & $\begin{array}{l}-0.0734 \\
(0.66)\end{array}$ \\
\hline Higher Education & $\begin{array}{l}0.933^{* *} \\
(0.010) \\
\end{array}$ & $\begin{array}{l}0.869^{*} \\
(0.45) \\
\end{array}$ & $\begin{array}{l}0.742^{\star \star} \\
(0.31)\end{array}$ & $\begin{array}{l}0.440^{\star \star \star} \\
(0.080)\end{array}$ \\
\hline Non-Western Immigrant ${ }^{\mathrm{b}}$ & $\begin{array}{l}-1.54^{*} \\
(0.85) \\
\end{array}$ & $\begin{array}{l}-0.771^{*} \\
(0.51) \\
\end{array}$ & $\begin{array}{l}-0.158 \\
(0.55)\end{array}$ & $\begin{array}{l}-0.192 \\
(0.20)\end{array}$ \\
\hline $\begin{array}{l}\text { N } \\
\text { Pseudo } R^{2}\end{array}$ & $\begin{array}{l}80 \\
0.408\end{array}$ & $\begin{array}{l}80 \\
0.187\end{array}$ & $\begin{array}{l}80 \\
0.124\end{array}$ & $\begin{array}{l}80 \\
0.207\end{array}$ \\
\hline
\end{tabular}

Comments: Logistic regression coefficients. Robust standard errors in brackets. Significance at two-sided test: ${ }^{* *} p<0.01{ }^{* *} p<0.05{ }^{*} p<0.1$. Three clusters according to school.

a The last 12 months before the interview, approximately ten years after the movement.

' The categories of "the East", "the West" and "the South" are constructed due to their proved difference on the effects of immigrant background and the level to which different groups risk being subjected to discrimination and prejudice (Myrberg 2007:32-43). Therefore, the categories are not in exact accordance with the geographical reality. "The South" includes people born in Africa, Asia (including the Middle East) and South America. "The East" refers to people born in South and Eastern Europe (including the Balkan) and "The West" includes people born in the Nordic countries, north-western Europe, Canada, the US, Australia and New Zeeland (Myrberg 2007:42). 
Figure 2.

Political Participation Today, Percentage of Respondents

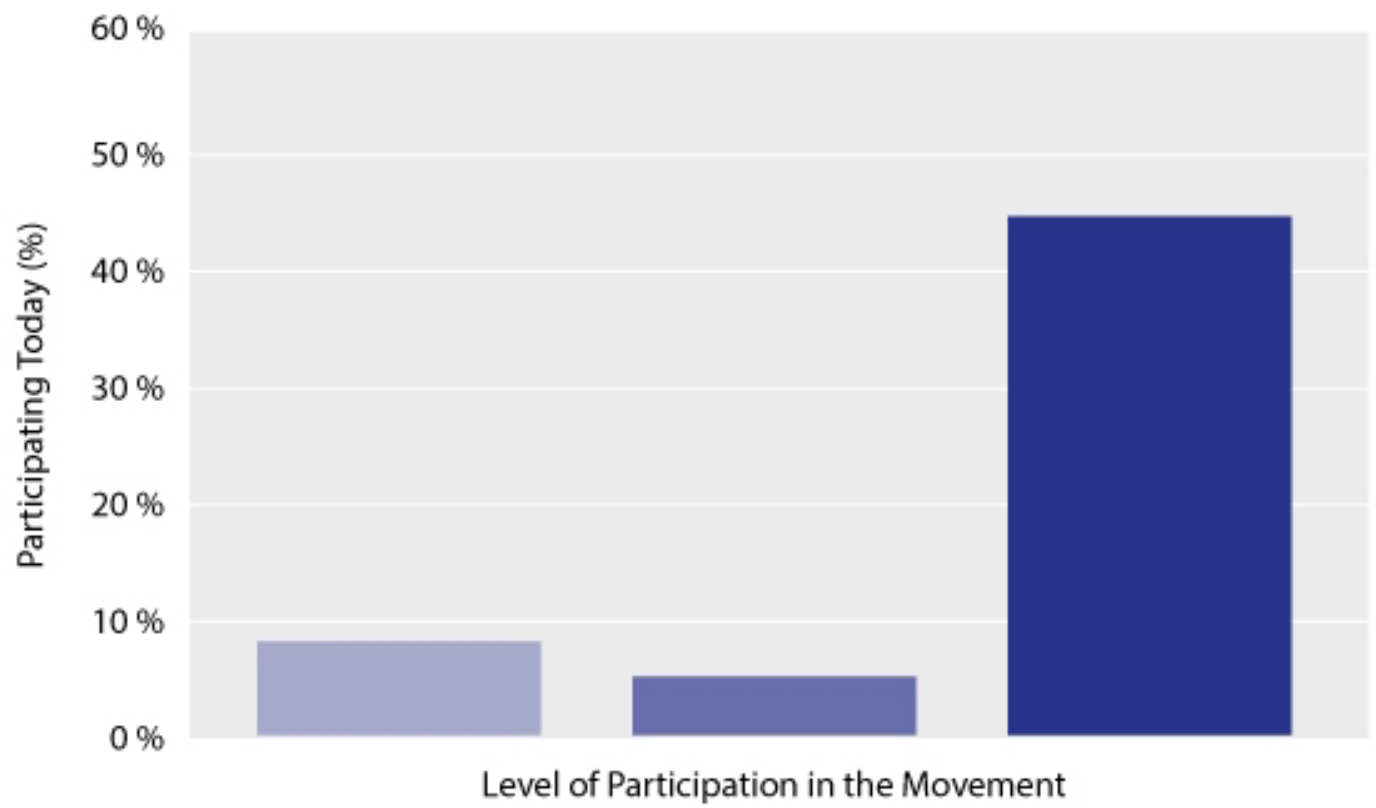

No Participation

Some Participation

High Level of Participation

sequences of activism, where the effect is triggered only at more regular participation of at least one hour per week on average.

\section{Explanatory Mechanisms}

Four variables are hypothesized to work as mechanisms explaining the relation between social movement participation and continued long-term political participation: internal political efficacy, external political efficacy, political interest and mobilizing networks. In the following analysis, I take steps towards examining whether these variables have a mediating effect on the relationship. In order for a variable to be considered a mechanism, it has to both be affected by activism at $t_{1}$ and affect participation at $t_{2}$. However, it should be noted that it cannot be fully established whether a mediating effect is in place. To enable this, it should also be confirmed that the effect of activism on long-term political participation is reduced. In this case, as we shall see, this relationship is further complicated by the interacting effects of movement success on the relationship.

Table IV illustrates the results from the analysis of the effects of participation in the movement on the hypothesized mechanisms.
Participation in the movement is found to have a significant effect on external efficacy, political interest and mobilizing networks. There was no significant effect of movement participation on internal political efficacy. It should be noted that causal relations can be particularly difficult to observe when including an interaction variable. Consequently, significant results are in this case more reliable indicators of causal relations than non-significant results are of non-correlation.

Participation in the movement is found to have a significant positive effect on political interest and mobilizing networks, indicating that social movement activism can result in increased networks and interest.

In previous research, political efficacy has been suggested to be affected by the success of the political activity in terms of reaching preferred policy outcome (e.g. Frey and Stutzer 2006), thus an interaction variable is included. When including the interaction effect in Model 2, movement participation is found to have a significant negative effect on external efficacy, and the interaction variable is found to have a significant positive effect. The results suggest that unsuccessful activism results in a negative effect on external efficacy. The effect of participation in a successful movement is the sum of the coefficients of 
Table IV.

Logistic Regression, Potential Mechanisms

\begin{tabular}{|c|c|c|c|c|c|c|}
\hline & \multicolumn{2}{|c|}{ External Efficacy } & \multicolumn{2}{|c|}{ Internal Efficacy } & \multirow{2}{*}{$\begin{array}{c}\text { Political } \\
\text { Interest }\end{array}$} & \multirow{2}{*}{$\begin{array}{c}\text { Mobilizing } \\
\text { Networks }\end{array}$} \\
\hline & Model 1 & Model 2 & Model 3 & Model 4 & & \\
\hline Participation in Movement, $\mathrm{t}_{1}$ & $\begin{array}{l}-1.03 \\
(1.17)\end{array}$ & $\begin{array}{l}-2.19^{* * *} \\
(0.59)\end{array}$ & $\begin{array}{l}1.72 \\
(1.6)\end{array}$ & $\begin{array}{l}1.79 \\
(1.8)\end{array}$ & $\begin{array}{l}2.25^{* * *} \\
(0.70)\end{array}$ & $\begin{array}{l}2.51^{* * *} \\
(0.91)\end{array}$ \\
\hline Success/No School Closure & & $\begin{array}{l}-0.304 \\
(0.41)\end{array}$ & & $\begin{array}{l}0.728 \\
(0.46)\end{array}$ & & \\
\hline $\begin{array}{l}\text { Interaction } \\
\text { (Participation } \mathrm{t}_{1}{ }^{*} \text { Success) }\end{array}$ & & $\begin{array}{l}4.13^{* * *} \\
(0.63)\end{array}$ & & $\begin{array}{l}0.494 \\
(1.2)\end{array}$ & & \\
\hline $\begin{array}{l}\mathrm{N} \\
\text { Pseudo } \mathrm{R}^{2}\end{array}$ & $\begin{array}{l}80 \\
0.138\end{array}$ & $\begin{array}{l}80 \\
0.277\end{array}$ & $\begin{array}{l}80 \\
0.354\end{array}$ & $\begin{array}{l}80 \\
0.369\end{array}$ & $\begin{array}{l}68^{a} \\
0.257\end{array}$ & $\begin{array}{l}80 \\
0.207\end{array}$ \\
\hline
\end{tabular}

Comments: Logistic regression coefficients. Robust standard errors in brackets. Significance at two-sided test: ${ }^{* * *} p<0.01{ }^{* *} p<0.05{ }^{*} p<0.1$. Controlling for: non-western immigrant, higher education, female, participation before the movement. Three clusters according to school.

a Since all of the respondents participating before the movement also had a high level of political interest, these observations are removed. Only respondents who did not participate before the movement are included in the regression analysis. Consequently, the studied sampling consists of the 68 respondents who did not participate before the movement.

movement participation and the interaction variable, in this case 1.94. Consequently, it is implied that participation in a successful movement has a positive effect on external efficacy.

It should be noted that the value of these variables before the movement is not controlled for and that the respondents could have had the same attitudes before the movement. However, given that several potential confounders are controlled for and that a large share of the respondents expressed that their attitudes and beliefs had changed as a result of their experience of participating in the movement; it is less likely that the entire observed effect is spurious. The effect of movement activism on political efficacy and mobilizing networks is supported by further interview material, while the causality with regards to political interest is more difficult to determine. When analysing the answers of individual respondents, the causality of the relationship between movement participation and the mechanisms of mobilizing networks is further reinforced. Respondents were asked at what point they received the request to participate in an activity and by whom. Movement participants also described whether they had any contact or collaboration with other movement participants today. Many of the requests to participate after the movement were posed by other movement participants.

The effect of movement participation on external efficacy varied with the movement's outcome, indicating a clear relation between external efficacy and engagement in the movement. Moreover, the similarities in wordings when describing external efficacy beliefs among participants in unsuccessful movements imply that respondents formed their efficacy beliefs from similar experiences. Strikingly similar wordings were used by movement participants, in particular from those who had protested against the closure of Gustav Adolfsskolan. When the respondents were first asked about their general view on politics, more than 50 per cent of the activists from Gustav Adolfsskolan answered along the lines: "When politicians have decided something, they never change their mind, no matter what the people do." In addition, several of the activists from the other unsuccessful movement used the same formulation. However, none of the activists from the successful movement at Slottsvångsskolan or the non-activists expressed themselves in similar ways. Thus, there are some indications that movement participation did have an effect on external efficacy.

Having examined the first part of the causal chain, we move on to the second: the effect of the four potential mechanisms on political participation today. These relations have been established in previous research (see Sullivan and Riedel 2001; Verba, Brady and Schlozman 1995). However, the relations are here further explored by connecting them to social movement participation, as well as the factor of reaching the preferred policy outcome. The results of the regression analysis can be found in Table V.

External and internal political efficacies are indicated to have significant positive effects on political participation today. These results are in line with those of previous studies (e.g. Sullivan and Riedel 2001:4353). The coefficient for external political efficacy is 1.20 , which is an odds ratio of 3.32. The explanatory variables of networks and political interest are not found to significantly affect long-term political participation. However, mobilizing networks have a strong significant short-term effect on participation. 
Table V.

Logistic Regression, Political Participation after the Movement, $t_{2}$

\begin{tabular}{|c|c|c|c|}
\hline \multirow[t]{3}{*}{ Variables, $\mathrm{t}_{2}$} & \multicolumn{3}{|c|}{ Political participation, $\mathrm{t}_{2}$} \\
\hline & \multicolumn{2}{|c|}{ Today } & \multirow{2}{*}{$\frac{\text { After Movement }}{\text { Model } 3}$} \\
\hline & Model 1 & Model $2^{a}$ & \\
\hline \multicolumn{4}{|l|}{ Mechanisms } \\
\hline External Political Efficacy & $\begin{array}{l}1.20^{* *} \\
(0.55)\end{array}$ & & \\
\hline Internal Political Efficacy & $\begin{array}{l}1.98^{* * *} \\
(0.75)\end{array}$ & & \\
\hline Mobilizing Networks & & $\begin{array}{l}0.746 \\
(1.38)\end{array}$ & $\begin{array}{l}4.20^{* * *} \\
(0.60)\end{array}$ \\
\hline Political Interest & & $\begin{array}{l}0.864 \\
(0.55)\end{array}$ & $\begin{array}{l}0.346 \\
(1.6)\end{array}$ \\
\hline $\mathrm{N}$ & 80 & 80 & 80 \\
\hline Pseudo $\mathrm{R}^{2}$ & 0.218 & 0.107 & 0.497 \\
\hline
\end{tabular}

Comments: Logistic regression coefficients. Robust standard errors in brackets. Significance at two-sided test: ${ }^{* *} p<0.01{ }^{* *} p<0.05{ }^{*} p<0.1$. Controlling for: Non-western immigrant background, higher education, female and participation before the movement. Three clusters according to school.

a The variables of political interest and internal political efficacy are highly correlated. In order to avoid multicollinearity, the variables are separated into two different models.

Participation in the movement seems to have resulted in increased mobilizing networks shortly after the movement, but the effect did not last up to the present moment.

In sum, it is indicated that participation in the movement could have affected external political efficacy, political interest and mobilizing networks. However, out of these, only external political efficacy was indicated to affect long term political participation. Consequently, only external political efficacy fulfils the two criteria necessary to be considered as a potential mechanism explaining the relationship. Moreover, in line with previous research, political efficacy is found to be sensitive to the success of the movement. Participation in a successful activity is implied to have a positive effect on efficacy, while participation in an unsuccessful activity could have a negative effect on efficacy. However, variations in external efficacy are far from explaining the entire spin-off effect of movement participation. In particular, the analysis lacks explanation of the positive effects of activism in unsuccessful movements on political participation. Thus, further studies into other mechanisms would be needed, not only in order to determine whether there is a mediating effect of political efficacy, but also in order to find more mechanisms that could explain the relationship.

\section{The Conditions of the Effect}

Even though an effect of movement participation on long-term political participation is observed among high-level participants, far from all of the re- spondents who were very active in the movement are politically active today. Perceived procedural justice and outcome satisfaction is, in previous research, suggested to be of importance when explaining variations in the effect of political engagement on future political attitudes and participation (e.g. Westholm 2007; Frey and Stutzer 2006). The influence of these factors on continued participation is further explored in figure 3 , showing the proportion of the highly committed activists remaining politically active today depending on their experience of the movement and their level of efficacy.

The findings imply that participation today varies within the group of high-level participants depending on perceived procedural justice and external efficacy. In contrast, there are no differences in participation patterns between the high-level activists who reached the preferred policy outcome and those who did not. Reaching preferred outcome is thus not a factor found to affect long-term participation.

Within the group of high-level participants who perceived themselves as fairly treated during the movement, 67 per cent participates today. This is a larger proportion than the average proportion of high-level movement activists participating today, 43.5 per cent, and considerably larger than the proportion of 29 per cent participating today among the group perceiving themselves as having been unfairly treated.

The differences in participation patterns are similar when comparing respondents with high and low levels of perceived external efficacy. Sixty-seven per cent of the high-level activists with high political ef- 
Figure 3.

Political Participation Today $\left(t_{2}\right)$, Percentage of High-Level Movement Participants

Conditions/Mechanisms

\begin{tabular}{l|l} 
Procedural Justice & $\begin{array}{l}\text { Minimum Level or More } \\
\text { Below Minimum Level } \\
\text { Fair } \\
\text { Unfair }\end{array}$
\end{tabular}

Preferred Outcome

Reached

Not Reached

\begin{tabular}{l|l} 
External Efficacy & High \\
Low
\end{tabular}
Political Participation Today, Percentage of Respondents
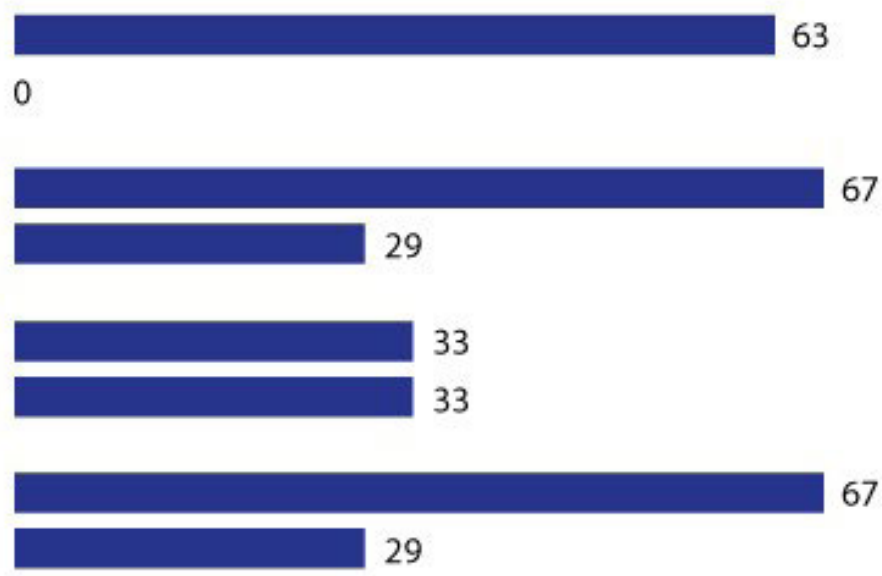

Comments: The numbers in the table refer to the percentage of the high-level movement activists in each category participating today. The result could be compared to the average proportion of high-level activists participating today $-43.5 \%$.

Below minimum level of procedural justice signifies that the treatment by the authorities was experienced as very unfair.

ficacy, and 29 per cent of the high-level activists with low political efficacy, participate today. Consequently, a strong effect of activism on political participation is identified among the respondents who participated at a high level in the movement and either have a high level of external efficacy beliefs or experienced a fair process.

In addition, it is indicated that a basic amount of perceived procedural justice is a condition that has to be fulfilled in order for any effect to take place. At very low levels of perceived procedural justice, such as in cases of discrimination due to ethnicity or immigrant background, the relationship between movement activism and participation today is completely dissolved. Out of the seven high-level movement activists perceiving that they were very unfairly treated, no one participates today. Five of these respondents were active before the movement. This indicates that high levels of participation in combination with an experience of having been very unfairly treated by the authorities can in fact result in decreased participation. However, given the limited participation before the movement among the respondents, no firm conclusions can be drawn regarding decrease in participation.

The in-depth interview material supports the findings. When explaining their lack of participation today, several of the respondents in this group express exhaustion, negative emotions and lack of trust in the political system. A respondent from Gustav Afolfsskolan said: "The whole process was a great sadness and a disappointment. After the clo- sure (of the school) I gave up everything. I did not participate again. I would not let myself be treated and humiliated in that way". Most of the respondents experiencing very unfair treatment describe their lack of participation today as a consequence of their previous experiences in the protests. As another respondent said: "I saw things in a different light before. I lived in a dream world and thought we had a real democracy, where the people could influence politics. I lost that naivety on the way". Consequently, the respondent's descriptions indicate that a part of the variation in participation today among high-level activists depends on their experience of the movement.

In addition, it should be noted that the answers of the respondents imply a great variation within the group who perceived the process as unfair. The strong statements quoted above could be compared to the descriptions by respondents who perceived the process as unfair, but who do not express the aspect of being personally discriminated against. One respondent from Norrehedskolan compares protesting to running into a padded wall: "you do not hurt yourself, but neither do you get anywhere". He describes that the politicians were "polite but did not take arguments or new information into fair consideration".

Similar variations could be found in political efficacy-beliefs, where the respondents expressing great disappointment with the fairness of the procedure also often expressed stronger negative emotions in relation to external efficacy. However, since efficacy is only measured dichotomously, this difference is 
not encompassed in the statistical analysis of efficacy. Overall, experience of the procedures as unfair largely corresponds with low efficacy beliefs. Among the very engaged protesters experiencing the procedure as fair, $89 \%$ have high external efficacy beliefs. The corresponding percentage among those experiencing the procedure as unfair is $7 \%$.

Not surprisingly, only a few of the respondents who reached the preferred outcome perceived the process as unfair. However, the experience of fairness was not perfectly predicted by outcome. Several of the participants in unsuccessful movements still perceived the process as fair.

In sum, perceived fairness of the process is indicated to be connected to both levels of external efficacy and participation patterns among the high-level participants. At the same time, the level of perceived fairness could be unevenly distributed, where some groups are more at risk at being unfairly treated by authorities. Given that there is an effect of procedural justice, this would also have implications on participation patterns. Table VI illustrates the levels of perceived procedural justice experienced in connection with the movement in each of the demographic groups.

Among the 23 very active movement participants, eight are born in non-western countries. In this group, only 12.5 per cent perceived the process as fair. The corresponding percentage in the group of westernborn high-level activists is $\mathbf{5 3 . 3}$ per cent. Similarly, procedural justice is perceived as higher among the group of high-level participants who had attended higher education, with 50 per cent perceiving the process as fair, than in the group that had not completed a year of higher education, where 22.2 per cent perceive the process as fair.

The differences in perceived procedural justice depending on demographic characteristics are implied to be connected to the observed effects of demographic variables on participation in the different time periods. The analysis finds a negative effect significant at the $10 \%$ level of non-western background on participation today, and a positive significant effect of higher education on participation today. These effects were not present before the period of movement activism. Consequently, the differences in participation patterns emerging after the movement could possibly be explained by different experiences of fairness in treatment by the authorities depending on immigration background and education.

In sum, it is implied that participation takes place only given that two conditions are fulfilled. Firstly, the level of participation has to be on a higher, more regular, basis. Secondly, there has to be a minimum level of perceived fairness reached in the response of the authorities to the activism.

The analysis does not support the assumption, often indirectly made in previous research (Cf. Giugni 2008), that the personal effects of movement participation are constant, independent of the experience and policy outcome of the movement. Among the studied protesters, the effect is observed to be very much dependent on the experience of the movement. Certain levels of participation in the movement and procedural justice have to be fulfilled in order for the effect to take place. The results support recent research indicating that the experience of the process could be of even greater importance than the policy outcome (see Frey and Stutzer 2006). This is found to be true not only in relation to external political efficacy, as has previously been suggested, but also in relation to political participation.

None of the high-level activists who perceived the process as very unfair participate politically today. Since the perception of procedural justice varied depending on education and immigrant background, it is indicated that participation triggered positive effect on long-term political participation mainly among those demographic groups that are less exposed to the risk of discrimination.

Table VI.

Perceiving the Procedure of School Closure as Fair, Percentage of High-Level Activists

\begin{tabular}{|c|c|c|c|c|c|c|c|}
\hline & \multicolumn{2}{|c|}{ Sex } & \multicolumn{2}{|c|}{ Education } & \multicolumn{2}{|c|}{ Born in... } & \multirow[t]{2}{*}{ Total } \\
\hline Procedural Fairness & Male & Female & Higher Education & $\begin{array}{c}\text { High School or } \\
\text { Less }\end{array}$ & The West & $\begin{array}{l}\text { The South/ } \\
\text { the East }\end{array}$ & \\
\hline Process Perceived as Fair & 46.2 & 70.0 & 50.0 & 22.2 & 53.3 & 12.5 & 39.1 \\
\hline $\mathrm{N}$ & 13 & 10 & 9 & 14 & 15 & 8 & 23 \\
\hline
\end{tabular}




\section{ConcLusion}

We have followed activists in their life-course ten years after their participation in the movement protesting against school closure. The personal commitment to the problem and acuteness of the situation mobilized people from all positions in society. Most of the activists had no previous participation in any political activity except for voting before. In this broad mobilization, we found it would be unlikely that people participated because they had a "taste" for activism.

The reduced risk of self-selection is one of the many ways in which the case of the movements against school closure differed from social movements previously examined in follow-up studies of activists. However, even in this context, so different from the American leftist movements in the 60 s and 70 s, a relationship between activism and long-term political participation was found. Activism changed the lifecourse of the protesters and empowered them into a more active citizenship.

The support of the spin-off effects of activism and the causality of the relation are further strengthened by the indications that external political efficacy could be one of the mechanisms explaining some of the relation. Movement participation could come to be an empowering force, strengthening the "beliefs about the responsiveness of governmental authorities and institutions to citizen demands" and thereby stimulating further participation.

However, these positive effects of activism did not occur among all protestors, and they were not evenly distributed with regards to demographical factors. Even though the movements mobilized many parents and teachers from marginalized groups, where political participation has been found to be lower than average, the activism did not positively affect the equality of participation. In fact, after the movement, the equality in participation, with respect to non-western immigrant background and education, decreased. In examining the conditions necessary to be fulfilled in order for the positive effect of activism on long-term political participation to be triggered, we found that the participation had to be at a higher level with regards to time spent. Moreover, none of the positive effect of activism was observed among the former protesters who had perceived treatment by the au- thorities as very unfair. Some of the activists, mostly from marginalized groups, told stories of degrading and discriminatory treatment from politicians and civil servants. This resulted in both decreased external efficacy and the elimination of the positive effects of activism on participation.

These results are in line with more recent studies within micro-democracy and political participation finding that that procedural justice was of greater importance in deciding future levels of participation than reaching the preferred policy outcome. Failure was not disempowering as long as the process was regarded as fair and democratic.

Even if the amount of people interviewed has been insufficient in order to draw wider and firm conclusions, the study illustrates what a process of political mobilization could look like. Provided that citizen engagement is met with respect by the authorities and that the demands of the activists are seriously taken into consideration, social movements have the possibility to not only change policies, but also to energize democracies, increasing the strength and equality of participation. In contrast, unfair treatment by authorities could have more wide-spread consequences than expected, eliminating positive spin-off effects of activism on further political participation. The marginalized groups, among which political participation is already lower, are exposed to a larger risk of experiencing an unfair process, which in turn eliminates the positive effects of activism

The results leave us with a warning regarding the generalizability of results of studies where procedural justice is not taken into consideration. The relationships found in previous follow up-studies of activism might not be applicable to all possible movements and activists - there are both thresholds of participation necessary to cross and conditions to fulfil in order for the effect to be triggered. Simply saying that social movement participation triggers future participation could, therefore, be a one-sided, and in some cases even false, statement. This calls for further studies into the complexities of biographical outcomes of activism and of how the interactions with the political authorities not only affect the policy consequences of the movement, but also the strong, personal and political effects of it.

\section{Notes}

1. It should be noted that neither Westhom et al. nor Frey et al. refer directly to political efficacy. Instead they discuss the similar conceptions of 'perceived opportunities' (Westholm and Erlach 2007:287) and 'utility' in terms of 'belief in political influence'(Frey and Stutzer 2006:395) Craig, Niemi and Silver (1990) divide these into regimebased external efficacy and incumbent-based external efficacy. See Craig et al (1990:307) for the complete list as well as categorization.

3. In the Swedish system: Kommunalval, landstingsval, and riskdagsval.

4. The period of movement activity at Slottsvångsskolan, $\mathrm{t}_{1}$, did not last a full six months. 


\section{References}

Armingeon, K. 2007. "Political Participation and Associational Involvement". Pp. 258-284 in Citizenship and Involvement in European Democracies - A Comparative Analysis, edited by J. W. Van Deth, J. R. Montero and A. Westholm. Abingdon: Routledge.

Brady, H. E. et al. 1999. "Political participation". Pp. 737797 in Measures of Political Attitudes, edited by J. P. Robinson, P. R. Shaver and L. S. Wrightsman. San Diego: Academic Press.

Brandt, C. and D. McAdam. 2009. "Assessing the Effects of Voluntary Youth Service: The Case of Teach for America." Social Forces 88: 945-969. http://dx.doi.org/10.1353/sof.0.0279

Campbell, A., G. Gerald and W.E. Miller. 1954. The Voter Decides. Evanston, IL: Row, Peterson.

Craig, S. C., R. G. Niemi and G. E. Silver. 1990. "Political efficacy and trust: A report on the NES pilot study items." Political Behavior 12: 289-314. http://dx.doi. org/10.1007/BF00992337

Dahl, R. 2000. On Democracy. New Haven: Yale University Press.

Van Dyke, N., D. McAdam and B. Wilhelm. 2000. "Gendered outcomes: Gender differences in the biographical consequences of activism." Mobilization: An International Quarterly 5(2): 161-177.

Finkel, S. E. 1987. "The effects of participation on political efficacy and political support: Evidence from a West German panel". The Journal of Politics 49(02): 441-464. http://dx.doi.org/10.2307/2131308

Frey, B. S. and A. Stutzer. 2006. "Political Participation and Procedural Utility: An Empirical Study." European Journal of Political Research 45: 391-418. http://dx.doi. org/10.1111/j.1475-6765.2006.00303.x

Giugni, M. G. 2008. "Political, Biographical and Cultural Consequences of Social Movements." Sociology Compass 2/5: 1582-1600. http://dx.doi.org/10.1111/j.17519020.2008.00152.x

Giugni, M. G. 2004. "Personal and Biographical Consequences." Pp. 489-506 in The Blackwell Companion to Social Movements, edited by D. A. Snow, S. A Soule and H. Kriesi. Oxford, UK: Blackwell. http://dx.doi.org/10.1002/9780470999103.ch21

Jennings, M. K. 1987. "Residues of a Movement: The Aging American Protest Generation." American Political Science Review 81: 367-82. http://dx.doi. org/10.2307/1961957

Jennings, M. Kent and R.G. Niemi. 1981. Generations and Politics. Princeton: Princeton University Press. http://dx.doi.org/10.1515/9781400854264

Kriesi, H., and A. Westholm. 2007. "Small-Scale Democracy - The Determinants of Action." Pp. 255-280 in Citizenship and Involvement in European Democracies - A Comparative Analysis, edited by J. W. Van Deth, J. R. Montero and A. Westholm. Abingdon: Routledge.
McAdam, Doug. 1999. "The Biographical Impact of Activism." Pp. 119-149 in How Social Movements Matter, edited by M. Giugni, D. McAdam and C. Tilly. Minneapolis: University of Minnesota Press.

McAdam, D., G.F. Davis, W. R. Scott and M. N. Zald. 2005. Social Movement and Organization Theory. Cambridge : Cambridge University Press.

Myrberg, G. 2007. Medlemmar och medborgare - Föreningsdeltagande och politiskt engagemang $i$ det etnifierade samhället. Uppsala, Uppsala universitet.

Niemi, R. G., S. C. Craig and F. Mattei. 1991. "Measuring internal political efficacy in the 1988 National Election Study." American Political Science Review, 85(04): 1407-1413. http://dx.doi.org/10.2307/1963953

Schlozman, K. L., Verba, S. \&Brady, H. E. 2012. The Unheavenly Chorus: Unequal Political Voice and the Broken Promise of American Democracy. Princeton University Press. http://dx.doi.org/10.1515/9781400841912

Schlozman, K. L., Verba, S., \& Brady, H. E. (1999). "Civic participation and the equality problem". Pp. 427-59 in Civic engagement in American democracy, edited by T. Skocpol and M. P. Fiorina. Washington D.C: Brookings Institution Press.

Sherkat, D. E. and T. J. Blocker. 1997. "Explaining the Political and Personal Consequences of Protest." Social Forces 75: 1049-70. http://dx.doi.org/10.2307/2580530 / http:// dx.doi.org/10.1093/sf/75.3.1049

Sullivan, J. L., and E. Riedel. 2001. "Efficacy: Political." Pp. 4353-4356 in International encyclopedia of social \& behavioral sciences.

Tarrow, S. 1998. Power in Movement - Social Movements and Contentious Politics. Cambridge: Cambridge University Press. http://dx.doi.org/10.1017/CBO9780511813245

Uba, K. 2010. "Save our school! What kinds of impact have protesters against school closures in Swedish local politics?" Statsvetenskaplig Tidsskrift 112: 96-104.

Verba, S., N. H Nie and J. O. Kim. 1978. Participation and political equality: A seven-nation comparison. University of Chicago Press.

Verba, S., H. E. Brady, and K. L. Schlozman. 1995. Voice and Equality: Civic Voluntarism in American Politics. Cambridge: Harvard University Press.

Westholm, A. and R. G. Niemi. 1986. "Youth Unemployment and Political Alienation." Youth and Society 18(1): 58-80. http://dx.doi.org/10.1177/0044118X86018001004

Westholm, A. and E. von Erlach. 2007. "Small-Scale Democracy - The Consequences of Action." In Citizenship and Involvement in European Democracies - A Comparative Analysis. Abingdon: Routledge.

Wilhelm, B. 1998. "Changes in Cohabitation across Cohorts: The Influence of Political Activism." Social Forces 77: 289310. http://dx.doi.org/10.1093/sf/77.1.289 / http://dx.doi. org/10.2307/3006018 


\section{APPENDIX}

Table 1.

Descriptive Statistics, Percentage of Respondents (from each School, activists and control group)

\begin{tabular}{|c|c|c|c|c|c|c|c|c|}
\hline \multirow[t]{2}{*}{ Variables } & \multicolumn{2}{|c|}{$\begin{array}{c}\text { Gustav Adolfsskolan } \\
\text { (Closure) }\end{array}$} & \multicolumn{2}{|c|}{$\begin{array}{c}\text { Slottsvångs-skolan } \\
\text { (No Closure) }\end{array}$} & \multicolumn{2}{|c|}{$\begin{array}{c}\text { Norrehed-skolan } \\
\text { (Closure) }\end{array}$} & \multicolumn{2}{|r|}{ Total } \\
\hline & Activists & Control-group & Activists & Control-group & Activists & Control-group & Activists & Control-group \\
\hline Female & 53,4 & 46,2 & 55,6 & 46,2 & 53,8 & 45,5 & 53,5 & 45,9 \\
\hline Higher Education & 23,8 & 15,4 & 66,7 & 76,9 & 69,2 & 36,4 & 46,5 & 43,2 \\
\hline $\begin{array}{l}\text { Non-Western } \\
\text { Immigrant }\end{array}$ & 76,2 & 100 & 22,2 & 0 & 0 & 9,1 & 41,9 & 37,8 \\
\hline$\%$ & 61,8 & 32,3 & 40,9 & 59,1 & 54,2 & 45,8 & 53,8 & 46,3 \\
\hline $\mathrm{N}$ & 21 & 13 & 9 & 13 & 13 & 11 & 43 & 37 \\
\hline
\end{tabular}

\section{INTERVIEW GUIDE}

\section{Political Participation}

Apart from voting, have you ever participated politically? What did you do? Elaborate!

\subsection{Voting}

In talking to people about elections, we find that they are sometimes not able to vote because they don't have time, or they have difficulty getting to the polls. Think about the national, regional and local elections ${ }^{3}$ since you were old enough to vote. Have you voted in all of them, in some of them, rarely voted in them, or have you never voted in an election? When and in which ones have you voted? /When did you not vote?

\subsection{Media}

Have you ever participated in media or social media for any political cause, such as writing debate articles, being interviewed, had a political blog etc.?

- When?

- What activity?

- How much time was spent?

\subsection{Communal Activity}

Have you gotten together or worked with others in your community or neighbourhood to try to deal with some community issue or problem?

If yes:

- Type of activity: formal (any official local governmental board or council that deals with community problems and issues. i.e. local council, school board etc.) /informal?

- Specify activity and frequency (e.g.: hours per week).

\subsection{Contacting}

Have you ever initiated any contacts with an elected official (at local, regional or national level) or a member of staff related to such an official? (Please don't count any contacts you have made as a regular part of your job)

If yes: Describe!

Possibly elaborate on:

- On what type of issue?

- When/how long ago (time periods)?

- Frequency (how many times?)

\subsection{Protesting}

Have you ever taken part in a protest, march, or demonstration on some national or local issue?

If yes:

- On what issues?

- When (time periods)?

- How many times/frequency (for every time period)?

\subsection{Political Organization}

Are you/have you been a member of a political organization? Have you attended any meetings of a political organization?

If yes:

- Does this organization take stands on any public issues- either locally or nationally?

- Which organization/type of organization?

- When (time periods)?

- Type of activity and frequency? (attended meetings, been an active member, served on a board?) 


\section{Mechanisms}

Political efficacy: Do you in general believe that activities other than voting could affect political decisions?

- Would you always have answered like that or did you ever change your view?

- (How would you have previously answered?)

- When did you change your view/opinion?

- What made you change your view/opinion?

\section{The Movement Against School Closure}

Did you participate in any activities to protest against the proposed closure of Norrehedskolan/ Slottsvångsskolan/Gustav Adlofsskolan?

What do you remember from this period? (What did you do? How much time did you spend?)

(Examples of activities: Did you participate in demonstrations, write debate articles, or collect signatures? Did you contact public officials or members of a board? Did you attended meetings, join or work through a political party, attend meetings with the parent association, attend meetings with Helsingborgs skolförening or with Nätverket mot skolnedläggelser? etc.)

When you first heard of the proposal to close the school, did you believe it would be possible to make the politicians change their decision?

How did the politicians/public officials react to your activities?

How did you feel when you heard about the decision to finally close/not close the school?

Did your learn anything from this period? What? Do you believe that the struggle against school closure has affected your views and opinions today and your level of participation? How? Why?

Would you have done it again?

Have you had any contact with anyone from the time of the protests? Have you received any request directed at you personally to take part in a political activity?

\section{Control Variables}

Education: What is your occupation/ profession? What education is needed for this job? Do you have any education apart from that?

Country of birth: Some people have described that they felt they were being discriminated against during the time of the protest because of their immigrant background - did you perceive that there was any discrimination? Were you born in Sweden? Where were you born?
Political interest: How interested would you say that you are in public affairs?

Mobilizing Networks: Have you received any request directed at you personally to take part in a political activity? When? How do you know the person who contacted you?

\section{List of Variables and Codings}

\section{Political Participation}

Political Participation, $\mathrm{t}_{0}$ and $\mathrm{t}_{1}$

Participation in any of the following modes of participation (participation $=1$; no participation $=0$ ):

- Media: Participating politically in regular or social media, i.e. writing articles, being interviewed.

- Contacting: Contacting government officials.

- Protest activity: Taking part in a protest, march, or demonstration

- Community activity: Working formally or informally with others in the community to deal with some community issue or problem

- Political organization: Attending meetings of a political organization.

\section{Voting}

Voting: Voting in state, national or local election. ( voted $=1$, did not vote $=0$ )

\section{Participation in the Movement, $t_{1}$}

Participated in the movement against school closure in any of the following modes of participation (participation $=1$; no participation $=0$ ):

- Media: Participating politically in regular or social media, i.e. writing articles, being interviewed.

- Contacting: Contacting government officials.

- Protest activity: Taking part in a protest, march, or demonstration

- Community activity: Working formally or informally with others in the community to deal with some community issue or problem

- Political organization: Attending meetings of a political organization.

High Level of Participation in the Movement, $\mathrm{t}_{1}$

Gustav Adolfsskolan and Norrehedskolan: Participated in the movement against school closure more than one hour per weekend during at least 6 months of the relevant time period $=1$. Any less participation $=0$.

Slottsvångsskolan ${ }^{4}$ : Participation during approximately the whole period of $t_{1}$ of more than one hour per week $=1$. Any less participation $=0$. 


\section{Control Variables}

Political Participation in $t_{0}$ (see above)

Female $(\operatorname{man}=0$, woman $=1)$

Higher Education (Completed 1 or more years of higher education $=1$, otherwise $=0$ )

Non-Western Immigrant Background (born in the South or the East=1, born in the West $=0$ )

Immigrants born in "the South or "the East" and not in "the West". The categories of the South, the East and the West are constructed according to the risk of being subjected to prejudice and discrimination, rather than the geographical boundaries. The South and the East refer to people born in: Africa, Asia (including the Middle East), South America and southern and eastern Europe (including the Balkans). Immigrants born in the South and the East do not include people born in Sweden or immigrants born in the Nordic countries, north-western Europe, Canada, the US, Australia or New Zeeland.

\section{Potential Mechanisms}

\section{Internal Political Efficacy}

High internal political efficacy: Believes in one's own competence to understand and to participate effectively in politics $=1$, otherwise $=0$

\section{External Political Efficacy}

High external efficacy: Believes in the responsiveness of governmental authorities and institutions to citizen demands $=1$, otherwise $=0$

Examples of statements indicating high/low internal/external efficacy may be found in the section "Political Efficacy" above.

Interest in Public Affairs: Claimed interest in politics $=1$, no interest $=0$

Mobilizing Networks: (gained through the movement)

SOFIA HELANDER, MA, is a doctoral candidate at the Department of Government, Uppsala University, Sweden. Her research areas include democratic theory, political engagement and social movements. Empirically, she has studied protest movements in Sweden and Kerala, India. Her work has appeared in Journal of Developing Societies. Her PhD project is focused on problems of political apathy and antagonism in radical democratic theory.
Received request during $t_{2}$ directed at respondent personally to take part in a political activity $=1$, otherwise $=0$

\section{Perception of Movement and Outcome}

Factors solely related to the perception of the movement against school closure and its outcome. The factors only concern people engaged in a movement.

\section{Policy Outcome}

\section{Preferred Policy Outcome Reached}

Preferred policy outcome reached: No closure. Involvement in movement against closure of Slottsvångsskolan $=1$

Preferred policy outcome not reached: Closure. Involved in movement against closure of Gustav Adolfsskolan or Norrehedsskolan $=0$

\section{Perceived Procedural Justice}

Subjective perception of the fairness/justice of the political decision making process. The indicators concern the procedure rather than the outcome and relate to the concept of fairness. Indicators could be given by explicit statements by respondents (i.e. "the process was not fair"/ "I was/we were not fairly treated") or indications concerning explanations given (i.e. "politicians couldn't even respond to our requests, they gave us no explanation of any relevance") or perceived discrimination due to belonging to a particular social group.

\section{Fair}

Treatment perceived as fair (reasonable explanation given) $=1$, unfair $=0$

\section{Very Unfair}

Basic level of fairness $=1$, treatment of public officials during the process perceived as very unfair (such as personally humiliating, degrading, or discriminating due to, for example, ethnicity, immigrant background, educational background or social status) $=0$ 